\title{
Pengaruh Pembelajaran Akidah Akhlak Terhadap Karakter Disiplin Siswadi MI Darul Falah Pematang Benteng Hilir
}

\author{
${ }^{1}$ Annor Saputra, ${ }^{2}$ Ahmad Rifa'i \\ Instruktur Tahfiz Sekolah Tinggi Ilmu Al-Quran, Dosen Sekolah Tinggi Ilmu Al- \\ Quran Amuntai \\ annorsaputra454@gmail.com, ahmadrifai210788@gmail.com
}

\begin{abstract}
Abstrak
Pembelajaran akidah akhlak termasuk faktor penting dalam pendidikan anak, kemunduran anak di sekolah sering disebabkan oleh keadaan pembelajaran di sekolah. Melalui pembelajaran akidah akhlak maka akan sangat membantu anak untuk berperilaku baik atau berakhlakul karimah. Baik buruknya pembelajaran akidah akhlak turut mempengaruhi terhadap perilaku siswa, karena sekolah ikut serta dalam upaya membentuk karakter seorang anak.

Dalam penelitian ini, metode yang digunakan adalah menggunakan metode kuantitatif, dan teknik pengambilan datanya dilakukan dengan angket atau kuesioner. Sedangkan teknik analisis datanya melalui pendekatan statistik regresi.

Berdasarkan hasil analisis data maka diperoleh hasil bahwa analisis pengolahan data yang terkumpul dari nilai variabel pembelajaran akidah akhlak dan karakter disiplin siswa dengan menggunakan teknik regresi, untuk mengetahui seberapa jauh pengaruh pembelajaran akidah akhlak terhadap karakter disiplin siswa yang di variabelkan menjadi $\mathrm{X}$ dan $\mathrm{Y}$ sehingga diketahui hasil perhitungannya. Selanjutnya dilakukan pembuktian analisis uji hipotesis yaitu dengan menggunakan program SPSS versi22.0 for windows dan didapatkan nilai r 0,976 dan nilair ${ }^{2} 0,954$ yang berarti hasil perhitungan yang telah diketahui bahwa pengaruh pembelajaran akidah akhlak terhadap karakter disiplin siswa mencapai 95,4\%, dengan kata lain karakter disiplin siswa MI Darul Falah Pematang Benteng Hilir dipengaruhi oleh pembelajaran akidah akhlaksebesar 95,4\%, sedangkan yang 4,6\% lagi yaitu karakter disiplin siswa dipengaruhi oleh faktor-faktor lainnya baik dari dalam siswa itu sendiri maupun dari luar siswa itu sendiri. Dengan nilai signifikan $0,000<0,05$ maka hal ini menunjukkan bahwa adanya regresi antara variabel X dan variabel Y. Maka dapat di simpulkan bahwa pembelajaran akidah akhlak memiliki pengaruh yang signifikan dengan karakter disiplin siswa.
\end{abstract}

Kata kunci: Pembelajaran, Akidah Akhlak, Karakter, Disiplin Siswa 


\section{PENDAHULUAN}

Pembelajaran merupakan suatu sistem yang terdiri atas berbagai komponen yang saling berhubungan dan mempengaruhi. Komponen tersebut adalah tujuan, materi, metode dan evaluasi. Dari keempat komponen pembelajaran itu, tujuan dijadikan fokus utama pengembangan, artinya ketiga komponen lainnya harus dikembangkan dengan mengacu pada komponen tujuan. ${ }^{1}$

Pembelajaran pada hakikatnya adalah proses sebab akibat. Guru sebagai pengajar merupakan penyebab utama terjadinya proses pembelajaran siswa, meskipun tidak semua perbuatan belajar siswa merupakan akibat guru yang mengajar. Oleh sebab itu, guru sebagai figur sentral, harus mampu menetapkan strategi pembelajaran yang tepat sehingga dapat mendorong terjadinya perbuatan belajar siswa yang aktif, produktif, dan efisien.

Siswa sebagai peserta didik merupakan subjek utama dalam proses pembelajaran. Keberhasilan pencapaian tujuan banyak tergantung kepada kesiapan dan cara belajar yang dilakukan siswa. Cara belajar ini dapat dilakukan dalam bentuk kelompok (klasikal) ataupun perorangan (individual). Oleh karena itu, guru dalam mengajar harus memperhatikan kesiapan, tingkat kematangan, dan cara belajar siswa.

Tujuan pembelajaran merupakan rumusan prilaku yang telah ditetapkan sebelumnya agar tampak pada diri siswa sebagai akibat dari perbuatan belajar yang telah dilakukan. Menurut Bloom, dkk. Tujuan pembelajaran dapat dipilih menjadi tujuan yang bersifat kognitif (pengetahuan), efektif (sikap), dan psikomotorik (keterampilan). Derajat pencapaian tujuan pembelajaran ini merupakan indikator kualitas pencapaian tujuan dan hasil perbuatan belajar siswa. ${ }^{2}$

Prosedur pembelajaran berbasis karakter merupakan keseluruhan proses usaha belajar dan pembentukan karakter peserta didik yang direncanakan. Untuk

\footnotetext{
${ }^{1}$ Asep Herry Hernawan, dkk, Pengembangan Kurikulum dan Pembelajaran Cet.19 (Tanggerang Selatan: Universitas Terbuka, 2013), h. 4.1.

${ }^{2}$ Asep Herry Hernawan, dkk, Pengembangan Kurikulum dan Pembelajaran..., h. 9.4.
} 
kepentingan tersebut, kompetensi, materi standar, indikator hasil belajar, PBK, dan waktu yang diperlukan harus ditetapkan sesuai dengan kepentingan pembelajaran sehingga peserta didik diharapkan memperoleh kesempatan dan pengelaman belajar yang optimal. Dalam hal ini, pembelajaran pada hakikatnya adalah proses interaksi antara peserta didik dengan lingkungannya, sehingga terjadi perubahan terjadi perilaku ke arah yang lebih baik. Dalam interaksi tersebut banyak sekali faktor yang mempengaruhinya, baik faktor internal yang datang dari dalam diri individu, maupun faktor eksternal yang datang dari lingkungan. ${ }^{3}$

Salah satu materi yang diajarkan dalam mata pelajaran pendidikan agama di lembaga pendidikan Islam adalah akhlak di samping akidah, ibadah (figh), Alquran, sejarah Islam. Akhlak memegang posisi kunci dalam pendidikan agama. Orang selalu mengaitkan akhlak dengan indikasi keberhasilan pendidikan agama. Apabila seorang anak berperilaku baik, sopan, santun tidak membuat masalah maka dengan mudah orang akan menilai bahwa pendidikan agama yang diterimanya berhasil, dan demikian juga sebaliknya.

Al-Abrasyi seorang pakar pendidikan Islam dari mesir mengemukakan lima tujuan umum tujuan pendidikan Islam. Salah satunya menurut beliau yang paling utama adalah pendidikan akhlak.

Dalam kajian keislaman dilihat betapa banyak landasan teoretis yang menempatkan betapa urgennya akhlak dalam Islam, di antaranyaHadits Nabi yang amat populer menyebutkan bahwa Rasulullah SAW. diutus untuk menyempurnakan akhlak, dan dalam banyak hadits lain selalu dikaitkan bahwa ukuran keislaman seseorang dilihat dari baik tidaknya akhlaknya.

Pendidikan akhlak secara makro mencakup tiga hal yaitu: ada akhlak yang menyentuh kognitif (sekedar pengetahuan tentang apa yang baik dan buruk); kedua ada pada tataran nilai (yakni mencintai nilai baik dan membenci nilai

${ }^{3}$ E. Mulyasa, manajemen pendidikan karakter (Jakarta: Bumi Aksara, 2014), h. 138. 
buruk); tataran ketiga melaksanakan perbuatan baik dalam kehidupannya seharihari dan menjauhi nilai buruk.

Akhlak ditempatkan sebagai bagian yang penting dalam pembinaan sumber daya manusia, sebab akhlak terkait erat dengan charakter building dari suatu bangsa. Pembangunan karakter itu penting karena menyangkut tentang pembangunan rohani manusia. Pembangunan rohani itu penting karena akhlak merupakan asas dari pembangunan manusia. ${ }^{4}$

Dalam akidah akhlak yang sering kali membicarakan suatu yang bersifat abstrak, sehingga dalam mengerjakannya dibutuhkan pemilihan metode pembelajaran yang tepat. Agar apa yang diajarkan tadi bisa dipahami dan diterima dengan baik oleh anak-anak, mengingat anak-anak adalah pribadi yang terbatas dalam kemampuannya menerima pelajaran.

Dengan pembelajaran akidah akhlak diharapkan dapat menumbuhkan dan meningkatkan keimanan siswa yang diwujudkan dalam tingkah laku terpuji. Karena tingkah laku ditentukan oleh keseluruhan pengalaman yang didasari oleh pribadi seseorang. Kesadaran merupakan sebab dari tingkah laku. Artinya, bahwa apa yang dipikir dan dirasakan oleh individu itu menentukan apa yang akan dikerjakan. Adanya nilai yang dominan mewarnai seluruh kepribadian seseorang dan ikut serta menetukan tingkah lakunya. Dengan demikian dapat disadari betapa pentingnya peranan pembelajaran akidah akhlak dalam membentuk tingkah laku siswa seutuhnya. ${ }^{5}$

Hal ini sesuai dengan penelitian terdahulu yang dilakukan oleh Syifa Fauziyah (2016), dengan judul Pengaruh Pembelajaran Akidah Akhlak Terhadap Perilaku Siswa Kelas V Sdi Darul Mu’minin Ciledug Tangerang. Dari hasil penelitian menunjukkan bahwa ada pengaruh secara signifikan antara

${ }^{4}$ Haidir Putra Daulay, Pemberdayaan Pendidikan Islam Di Indonesia (Jakarta: Rineka Cipta, 2009), h. 103.

${ }^{5}$ Krismi Winayang Sari, Pengaruh Pendidikan Aqidah Akhlak Terhadap Perilaku Siswa Kelas II di MI Al-Hikmah Mampang Jakarta Selatan (Jakarta:2014), h. 5. 
Pembelajaran Akidah Akhlak terhadap Perilaku Siswa kelas V SDI Darul Mu'minin Ciledug Tangerang.

Adapun peneliti terdahulu yang dilakukan oleh Krismi Winayang Sari (2014), dengan judul Pengaruh Pembelajaran Akidah Akhlak Terhadap Perilaku Siswa Kelas II Di MI Al-Hikmah Mampang Jakarta Selatan. Dari hipotesis penelitian yaitu terdapatnya pengaruh positif yang signifikan antara pembelajaran akidah akhlak terhadap pembentukan akhlak siswa kelas II MI Al-Hikmah Jakarta Selatan.

\section{METODE PENELITIAN}

Jenis penelitian yang dilakukan oleh peneliti adalah menggunakan penelitian yang bersifat penelitian lapangan (Field Research), ${ }^{6}$ yaitu penelitian yang dilakukan dengan terjun kelapanganuntuk menggali dan menghimpun data yang diperlukan mengenai pengaruh pembelajaran akidah akhlak terhadap karakter disiplin siswa di MI Darul Falah Desa Pematang Benteng Hilir. Dengan demikian dalam penelitian ini penulis menggunakan pendekatan metode kuantitatif.

Metode ini sebagai metode ilmiah/scientific karena telah memenuhi kaidah-kaidah ilmiah yaitu konkrit/empiris, objektif, terukur, rasional, dan sistematis. Metode ini juga disebut metode konfirmatif, karena metode ini cocok digunakan untuk pembuktian/konfirmasi. Metode ini disebut metode kuantitatif karena data penelitian berupa angka-angka dan analisis menggunakan statistik. ${ }^{7}$

Dengan demikian metode kuantitatif dapat diartikan sebagai metode penelitian yang berlandaskan pada filsafat positivisme, digunakan untuk meneliti pada populasi atau sampel tertentu, pengumpulan data menggunakan instrument penelitian, analisis data bersifat kuantitatif/statistik, dengan tujuan untuk menguji hipotesis yang telah ditetapkan. ${ }^{8}$

\footnotetext{
2008), h. 5.

${ }^{6}$ Iqbal Hasan, Analisis Data Penelitian Dengan Statistik Cet 3 (Jakarta: PT Bumi Aksara,

${ }^{7}$ Sugiyono, Metode Penelitian Kombinasi (Bandung: Alfabeta, 2016), h. 10.

${ }^{8}$ Sugiyono, Cara Mudah Skripsi, Tesis, dan Disertasi (Bandung: Alfabeta, 2016), h. 23.
} 
Metode yang digunakan dalam penelitian ini adalah metode penelitian regresi. Penelitian menggunakan metode regresi tersebut mencakupkegiatan pengumpulan data untuk mengetahui keeratan pengaruh antara variabel-variabel yang diteliti.

Dalam hal ini penulis meneliti pengaruh antara pembelajaran akidah akhlak sebagai variabel $\mathrm{X}$ atau disebut juga dengan variabel Independen (Variabel bebas) dan karakter disiplin siswa sebagai variabel Y atau variabel Dependen (variabel terikat).

\section{Hasil Penelitian}

1. Analisis Data

Tujuan dari analisis data yaitu untuk membuktikan ada tidaknya pengaruh pembelajaran akidah akhlak terhadap karakter disiplin siswadi MIDarul Falah Pematang Benteng Hilir.Peneliti akan menganalisis kedua variabel dengan menggunakan rumus regresi.

Dalam analisis deskriptif, peneliti akan menyajikan analisis data dalam rangka untuk mengetahui pengaruh pembelajaran akidah akhlak terhadap karakter disiplin siswadi MIDarul Falah Pematang Benteng Hilir.

a. Analisis Data Deskriptif Pembelajaran Akidah Akhlak

Pengambilan data mengenai pembelajaran akidah akhlak diperoleh dari penyebaran angket yang terdiri dari 22 item pertanyaan. Berikut adalah Blue Frint pembelajaran akidah akhlak: 
Tabel 4.7

Skala Pembelajaran Akidah Akhlak

\begin{tabular}{|c|l|c|c|c|}
\hline \multirow{2}{*}{ No } & \multirow{2}{*}{ Aspek } & \multicolumn{2}{|c|}{ Item } & \multirow{2}{*}{ TOTAL } \\
\cline { 3 - 4 } & & Favorable & Unfavorable & \\
\hline 1 & Pembinaan Iman & 20 & & 1 \\
\hline 2 & Pembinaan Akhlak & $1,4,8,15,16$ & 2,9 & 7 \\
\hline 3 & Pembinaan Ibadah & $5,6,22$ & & 11 \\
\hline \multirow{2}{*}{4} & Pembinaan Sosial Anak & $3,7,12,13,14$, & $10,11,17$ & \\
\hline & & $18,19,21$ & & 22 \\
\hline
\end{tabular}

Masing-masing pertanyaan tersedia 3 alternatif jawaban dengan bobot nilai sebagai berikut:

Tabel 4.8

Petunjuk Penilaian Angket

\begin{tabular}{|c|c|c|c|}
\hline \multirow{2}{*}{ Pernyataan } & \multicolumn{3}{|c|}{ Skor Angket } \\
\cline { 2 - 4 } & Ya & Kadang-kadang & Tidak \\
\hline Positif (+) & 3 & 2 & 1 \\
\hline Negatif (-) & 1 & 2 & 3 \\
\hline
\end{tabular}

Jumlah responden sejumlah 35 siswa. Berikut adalah daftar siswa beserta hasil angket.

Tabel 4.9

Skor Angket Pembelajaran Akidah Akhlak

\begin{tabular}{|l|l|c|c|l|c|}
\hline No & \multicolumn{1}{|c|}{ Nama } & Hasil & No & \multicolumn{1}{|c|}{ Nama } & Hasil \\
\hline 1 & Fini A. & 65 & 19 & M. Marzuki & 60 \\
\hline 2 & Habibi & 66 & 20 & M. Nasir & 63 \\
\hline 3 & Hafifah & 60 & 21 & M. Sufi & 62 \\
\hline 4 & Halisah & 63 & 22 & N. Hikmah & 59 \\
\hline 5 & Humaidi & 63 & 23 & Zama'ah & 56 \\
\hline 6 & Husna & 65 & 24 & Aditya R & 66 \\
\hline 7 & Mahmudah & 59 & 25 & A. Rusyadi & 60 \\
\hline 8 & M. Amin & 66 & 26 & A. Zailani & 57 \\
\hline
\end{tabular}


BADA'A: Jurnal Ilmiah Pendidikan Dasar

Vol. 2, No. 2, Desember 2020, Hal.164-179

E-ISSN: 2714-7711

\begin{tabular}{|l|l|c|l|l|c|}
\hline 9 & M. Budi & 31 & 27 & Fauziah & 50 \\
\hline 10 & M. Rajuddin & 55 & 28 & Mawardah & 63 \\
\hline 11 & Sa'adah & 55 & 29 & M. Arsyad & 51 \\
\hline 12 & S. Abdan & 66 & 30 & Nia R. & 65 \\
\hline 13 & Wati & 63 & 31 & Rahmi & 54 \\
\hline 14 & Arif R & 64 & 32 & Rukhaiyyah & 60 \\
\hline 15 & F. Arifin & 66 & 33 & Saubari & 57 \\
\hline 16 & Hamidah & 59 & 34 & Nafisah & 56 \\
\hline 17 & Mariyah & 65 & 35 & Nisa & 66 \\
\hline 18 & M. Baihaki & 57 & & & \\
\hline
\end{tabular}

Dari tabel di atas dapat disimpulkan bahwa angket pembelajaran akidah akhlak dengan jumlah 22 item soal diketahui nilai maksimum 66 dan nilai minimum 31 maka berdasarkan rumus intervalnya adalah sebagai berikut:

$$
i=\frac{(x t-x r)+1}{k i}
$$

Ket:

$\mathrm{i}=$ interval ideal

$\mathrm{xt}=$ nilai tertinggi ideal

$\mathrm{xr}=$ nilai terendah ideal

$$
\begin{gathered}
i=\frac{(66-31)+1}{3} \\
i=\frac{36}{3} \\
i=12
\end{gathered}
$$


Setelah diketahui lebar interval, dapat ditetapkan klarifikasi dalam tabel sebagai berikut:

Tabel 4.10

Interval Pembelajaran Akidah Akhlak

\begin{tabular}{|c|c|}
\hline Nilai & Kualifikasi Motivasi \\
\hline $66-78$ & Sangat Tinggi \\
\hline $53-65$ & Tinggi \\
\hline $40-52$ & Sedang \\
\hline $27-39$ & Rendah \\
\hline $14-26$ & Sangat Rendah \\
\hline
\end{tabular}

Setelah ditetapkan klarifikasi dalam kategori, maka dapat disimpulkan masing-masing skor dan nominasinya sebagai berikut:

Tabel 4.11

Kesimpulan Masing-Masing Skor dan Nominasi

\begin{tabular}{|c|c|c|c|c|c|}
\hline No & Nilai & Kategori & No & Nilai & Kategori \\
\hline 1 & 65 & $\mathrm{~T}$ & 19 & 60 & $\mathrm{~T}$ \\
\hline 2 & 66 & $\mathrm{ST}$ & 20 & 63 & $\mathrm{~T}$ \\
\hline 3 & 60 & $\mathrm{~T}$ & 21 & 62 & $\mathrm{~T}$ \\
\hline 4 & 63 & $\mathrm{~T}$ & 22 & 59 & $\mathrm{~T}$ \\
\hline 5 & 63 & $\mathrm{~T}$ & 23 & 56 & $\mathrm{~T}$ \\
\hline 6 & 65 & $\mathrm{~T}$ & 24 & 66 & $\mathrm{ST}$ \\
\hline 7 & 59 & $\mathrm{~T}$ & 25 & 60 & $\mathrm{~T}$ \\
\hline 8 & 66 & $\mathrm{ST}$ & 26 & 57 & $\mathrm{~T}$ \\
\hline 9 & 31 & $\mathrm{R}$ & 27 & 50 & $\mathrm{~S}$ \\
\hline 10 & 55 & $\mathrm{~T}$ & 28 & 63 & $\mathrm{~T}$ \\
\hline 11 & 55 & $\mathrm{~T}$ & 29 & 51 & $\mathrm{~S}$ \\
\hline 12 & 66 & $\mathrm{ST}$ & 30 & 65 & $\mathrm{~T}$ \\
\hline
\end{tabular}


BADA'A: Jurnal Ilmiah Pendidikan Dasar

Vol. 2, No. 2, Desember 2020, Hal.164-179

E-ISSN: 2714-7711

\begin{tabular}{|c|c|c|c|c|c|}
\hline 13 & 63 & $\mathrm{~T}$ & 31 & 54 & $\mathrm{~T}$ \\
\hline 14 & 64 & $\mathrm{~T}$ & 32 & 60 & $\mathrm{~T}$ \\
\hline 15 & 66 & $\mathrm{ST}$ & 33 & 57 & $\mathrm{~T}$ \\
\hline 16 & 59 & $\mathrm{~T}$ & 34 & 56 & $\mathrm{~T}$ \\
\hline 17 & 65 & $\mathrm{~T}$ & 34 & 66 & $\mathrm{ST}$ \\
\hline 18 & 57 & $\mathrm{~T}$ & & & \\
\hline
\end{tabular}

Dari data tabel tersebut maka dapat diketahui nilai sangat tinggi adalah 6 siswa, kategori Tinggi adalah 26 siswa, kategori Sedang adalah 2, kategori Rendah adalah 1 siswa dan Kategori Sangat Rendah 0. Setelah interval dan kategori didapat, maka ditentukan frekuensi dan presentase pembelajaran akidah akhlak yaitu sebagai berikut:

$$
\mathrm{P}=\frac{F}{N} 100 \%
$$

Keterangan :

$\mathrm{P}:$ Prosentase

F : Jumlah Objek

$\mathrm{N}$ : Frekuensi

1) Kategori skor sangat tinggi $: \mathrm{P}=\frac{F}{N} \times 100 \%$

$$
\begin{aligned}
& P=\frac{6}{35} \times 100 \% \\
& P=17,14 \%
\end{aligned}
$$

2) Kategori skor tinggi

$$
: \mathrm{P}=\frac{F}{N} \mathrm{x} 100 \%
$$

$$
\begin{aligned}
& P=\frac{26}{35} \times 100 \% \\
& P=74,28 \%
\end{aligned}
$$

3) Kategori skor sedang

$$
: \mathrm{P}=\frac{F}{N} \times 100 \%
$$

$$
P=\frac{2}{35} \times 100 \%
$$




$$
\begin{aligned}
\mathrm{P}= & 5,71 \% \\
& : \mathrm{P}=\frac{F}{N} \times 100 \% \\
\mathrm{P}= & \frac{1}{35} \times 100 \% \\
\mathrm{P}= & 2,85 \%
\end{aligned}
$$

4) Kategori skor rendah

5) Kategori skor sangat rendah $: \mathrm{P}=\frac{F}{N} \times 100 \%$

$$
\begin{aligned}
& P=\frac{0}{35} \times 100 \% \\
& P=0 \%
\end{aligned}
$$

Berdasarkan analisis data diatas dapat disimpulkan bahwa:

1) Kategori antara 66-78 berarti pembelajaran akidah akhlak dikatakan sangat tinggi sebanyak 6 siswa atau 17,14\%.

2) Kategori antara 53-65 berarti pembelajaran akidah akhlak dikatakan tinggi sebanyak 26 siswa atau 74,28\%.

3) Kategori antara 40-52 berarti pembelajaran akidah akhlak dikatakan sedang sebanyak 2 siswa atau 5,71\%.

4) Kategori antara 27-39 berarti pembelajaran akidah akhlakdikatakan rendah sebanyak 1 siswa atau 2,85\%.

5) Kategori antara 14-26 berarti pembelajaran akidah akhlak dikatakan sangat rendah sebanyak 0 siswa atau $0 \%$.

Maka pernyataan diatas menjawab rumusan masalah yang pertama yaitu "Seberapa tinggi tingkat hasil pembelajaran akidah akhlak siswa kelas IV, V dan VIdi MI Darul FalahPematang Benteng Hilir”.

b. Analisis Data Deskriptif Karakter Disiplin Siswa

Pengambilan data mengenai karakter disiplin siswa diperoleh dari penyebaran angket yang terdiri dari 18 item pertanyaan. Berikut adalah Blue Frint karakter disiplin siswa: 
Untuk mengetahui pengaruh pembelajaran akidah akhlak terhadap karakter disiplin siswa, dalam penelitian ini penulis menggunakan teknik analisis regresi dengan menggunakan bantuan program SPSS versi 22.0 for windows dengan hasil sebagai berikut:

Tabel 4.17

\section{Hasil Nilai Signifikan}

Model Summary ${ }^{b}$

\begin{tabular}{|l|c|r|r|r|r|}
\hline Model & $\mathrm{R}$ & R Square & $\begin{array}{c}\text { Adjusted R } \\
\text { Square }\end{array}$ & $\begin{array}{c}\text { Std. Error of } \\
\text { the Estimate }\end{array}$ & $\begin{array}{c}\text { Durbin- } \\
\text { Watson }\end{array}$ \\
\hline 1 & $.976^{\mathrm{a}}$ & .954 & .952 & 1.478 & 2.400 \\
\hline
\end{tabular}

Dari semua data yang diperoleh dan dianalisa dengan uji regresi maka didapatkan hasil dengan nilai r 0,976 dan nilair ${ }^{2} 0,954$ yang berarti hasil perhitungan yang telah diketahui bahwa pengaruh pembelajaran akidah akhlak terhadap karakter disiplin siswa mencapai 95,4\%, dengan kata lain karakter disiplin siswa MI Darul Falah Pematang Benteng Hilir dipengaruhi oleh pembelajaran akidah akhlaksebesar 95,4\%, sedangkan yang 4,6\% lagi yaitu karakter disiplin siswa dipengaruhi oleh faktor-faktor lainnya baik dari dalam siswa itu sendiri maupun dari luar siswa itu sendiri.

Maka pernyataan diatas menjawab rumusan masalah yang ketiga yaitu "Bagaimana pengaruh pembelajaran akidah akhlak terhadap karakter disiplin siswa kelas IV, V dan VI di MI Darul Falah Pematang Benteng Hilir."

\section{Analisis Uji Hipotesis}

Uji hipotesis penelitian ini menggunakan teknik analisis regresi dengan menggunakan bantuan program SPSS versi 22.0 for windows. Dari semua data yang sudah diperoleh dan dianalisa dengan uji regresi maka didapatkan hasil dengan nilai koefisien korelasi $r=0,976$. Hal ini menunjukkan semakin positif pembelajaran akidah akhlak maka semakin tinggi karakter disiplin siswa. 
Selain itu terdapat nilai koefisien determinasir ${ }^{2}$ sebesar 0,954 yang menunjukkan pembelajaran akidah akhlak memberikan sumbangan efektif sebesar 95,4\% terhadap karakter disiplin siswa. Kondisi ini mengindikasikan bahwa karakter disiplin pada siswa dipengaruhi oleh pembelajaran akidah akhlak sebesar 95,4\% dan sisanya 4,6\% dipengaruhi oleh faktor lain.

\section{Pembahasan}

Dalam penelitian ini dilakukan pengambilan data siswa dan sebaran angket tentang pengaruh pembelajaran akidah akhlak terhadap karakter disiplin siswa sebanyak 40 item pertanyaan. Pengambilan populasi sebanyak 71 siswa dan sampel sebanyak 35 siswa dari kelas tinggi, yaitu semua siswa yang ada di kelas 4,5,dan 6 .

Pada saat penelitian, peneliti membagi angket yang dilaksanakan pada hari jumat tanggal 22 Februari 2019. Peneliti memberikan angket kepada siswa dan pertanyaan-pertanyaan yang ada dalam angket harus dikerjakan sesuai dengan apa yang ada dalam diri masing-masing siswa. Dari angket yang dibagikan tersebut merupakan angket untuk mengetahui pengaruh pembelajaran akidah akhlak terhadap karakter disiplin siswa.

Berdasarkan hasil perhitungan pembelajaran akidah akhlak di ketahui kategori sangat tinggi sebanyak 6 siswa atau 17,14\%, dikatakan tinggi sebanyak 26 siswa atau 74,28\%, dikatakan sedang sebanyak 2 siswa atau 5,71\%, kategori rendah 1 siswa atau $2,85 \%$ dan kategori sangat rendah 0 siswa atau $0 \%$.

Sedangkan hasil perhitungan karakter disiplin siswa di ketahui kategori sangat tinggi sebanyak 6 siswa atau 17,14\%, dikatakan tinggi sebanyak 25 siswa atau 71,42\%, dikatakan sedang sebanyak 3 siswa atau 8,57\%, kategori rendah 1 siswa atau 2,85\% dan kategori sangat rendah 0 siswa atau $0 \%$.

Analisis pengolahan data yang terkumpul dari nilai variabel pembelajaran akidah akhlak dan karakter disiplin siswa dengan menggunakan teknik regresi untuk mengetahui seberapa jauh pengaruh pembelajaran akidah 
akhlak terhadap karakter disiplin siswa yang di variabelkan menjadi X dan Y sehingga diketahui hasil perhitungannya. Selanjutnya dilakukan pembuktian analisis uji hipotesis yaitu dengan menggunakan program SPSS versi 22.0 for windows dan didapatkan nilai r 0,976 dan nilair ${ }^{2}$ 0,954 yang berarti hasil perhitungan yang telah diketahui bahwa pengaruh pembelajaran akidah akhlak terhadap karakter disiplin siswa mencapai 95,4\%, dengan kata lain karakter disiplin siswa MI Darul Falah Pematang Benteng Hilir dipengaruhi oleh pembelajaran akidah akhlaksebesar 95,4\%, sedangkan yang 4,6\% lagi yaitu karakter disiplin siswa dipengaruhi oleh faktor-faktor lainnya baik dari dalam siswa itu sendiri maupun dari luar siswa itu sendiri.

Dalam penelitian ini nilai $\mathrm{F}$ yang diperoleh adalah $\mathrm{F}=676,690$ dengan $\operatorname{sig}=0,000$ maka sig $<0,05$ sehingga $\mathrm{H}_{0}$ ditolak artinya persamaan garis regresi adalah signifikan. Sehingga model regresi dapat diprediksi untuk mengetahui pengaruh pembelajaran akidah akhlak terhadap karakter disiplin siswa. Dengan nilai signifikan $0,000<0,05$ maka hal ini menunjukkan bahwa adanya regresi antara variabel X dan variabel Y. Maka dapat disimpulkan bahwa pembelajaran akidah akhlak memiliki pengaruh yang signifikan dengan karakter disiplin siswa.

Penelitian-penelitian yang dilakukan oleh peneliti lain yang sudah dilakukan oleh Hendi Sopandi tahun 2014, dengan judul Pengaruh Pembelajaran Akidah Akhlak Terhadap Perilaku Siswa di MI Persis Burungayun Sukakarya Banyu Resmi Garut. Hasil penelitian: Pertama, koefisien korelasinya termasuk kategori tinggi dengan skor 0,95, kedua, kadar hubungan pembelajaran akidah akhlak terhadap perilaku siswa sebesar 59\%, faktor lain yang turut mempengaruhi perilaku siswa sebesar $41 \%$, dan ketiga, hipotesisnya diterima, yaitu semakin bagus pembelajaran akidah akhlak maka semakin positif pula perilaku siswa, diketahui t hitung $=32,1$ dan $\mathrm{t}$ tabel $=1,65$ berdasarkan taraf signifikansi $5 \%$. 


\section{KESIMPULAN}

Pada bab ini peneliti akan mengemukakan beberapa kesimpulan yang merupakan hasil penelitian tentang pengaruh pembelajaran akidah akhlak terhadap karakter disiplin siswa yang mana penelitian ini bertempat di MI Darul Falah Pematang Benteng Hilir, kesimpulannya adalah:

1. Pembelajaran akidah akhlak kategori sangat tinggi mencapai $17,14 \%$, kategori tinggi mencapai 74,28\%, kategori sedang mencapai 5,71\%, kategori rendah mencapai 2,85\%, dan kategori sangat rendah $0 \%$.

2. Karakter disiplin siswa kategori sangat tinggi mencapai $17,14 \%$, kategori tinggi mencapai $71,42 \%$, kategori sedang mencapai 8,57\%, kategori rendah mencapai 2,85\%, dan kategori sangat rendah $0 \%$.

3. Pengaruh pembelajaran akidah akhlak memiliki regresi positif dan signifikan terhadap karakter disiplin siswa di MI Darul Falah Pematang Benteng Hilir, karena nilai $r^{2}$ yang diperoleh adalah sebesar 0,954, dengan ditemukan angka signifikan, maka hipotesis penelitian ini berbunyi ada pengaruh yang positif antara pembelajaran akidah akhlak terhadap karakter disiplin siswa. 
BADA'A: Jurnal Ilmiah Pendidikan Dasar

Vol. 2, No. 2, Desember 2020, Hal.164-179

E-ISSN: 2714-7711

\section{DAFTAR PUSTAKA}

Daulay, Haidir Putra. Pemberdayaan Pendidikan Islam Di Indonesia. Jakarta: Rineka Cipta, 2009.

E. Mulyasa. manajemen pendidikan karakter. Jakarta: Bumi Aksara, 2014.

Hasan, Iqbal.Analisis Data Penelitian Dengan Statistik Cet.3. Jakarta: PT Bumi Aksara, 2008.

Hernawan, Asep Herry,dkk.Pengembangan Kurikulum dan Pembelajaran. Tanggerang Selatan: Universitas Terbuka, 2013.

Sari,Krismi Winayang.Pengaruh Pendidikan Akidah Akhlak Terhadap Perilaku Siswa Kelas II di MI Al-Hikmah Mampang Jakarta Selatan. Jakarta, 2014.

Sugiyono. Cara Mudah Skripsi, Tesis, dan Disertasi. Bandung: ALFABETA, 2016.

Sugiyono. Metode Penelitian Kombinasi. Bandung: ALFABETA, 2017. 